\title{
Penerapan Strategi Index Card Match Untuk Meningkatkan Hasil Belajar Pendidikan Agama Islam
}

\author{
Jusnaini \\ Sekolah Dasar Negeri 9 Pekanbaru \\ e-mail: jusnaini09pekanbaru@gmail.com
}

\begin{abstract}
This research is motivated by the low learning outcomes of Islamic Education in fifth grade students of Public Elementary School (SDN) 9 Pekanbaru. The purpose of this study was to determine the increase in learning outcomes of Islamic Education in fifth grade students of SDN 9 Pekanbaru with the application of the index card match strategy. The method of this research is Class Action Research conducted in two cycles. Each cycle consists of two meetings and four stages, namely planning, implementation, observation, and reflection. The time of this research was conducted in April 2018 in the second semester of the 2017/2018 school year. As subjects in this study were one teacher and fifth grade students in the 2017-2018 school year with 22 students divided into 12 men and 10 women. Data collection techniques used in this study were observation and test techniques. Based on this study, data obtained that before the action of students who completed only 12 students or $54.55 \%$, after being given the action in the first cycle increased to 16 students or $72.73 \%$. In cycle II it increased again to reach 20 students or with a percentage of $90.91 \%$. So it can be concluded that the implementation of the index card match strategy can improve the learning outcomes of Islamic Education in fifth grade students of SDN 9 Pekanbaru.
\end{abstract}

Keywords: Index Card Match Strategy, Learning Outcomes of Islamic Education.

\section{PENDAHULUAN}

Kemampuan siswa dalam menerima pelajaran berbeda-beda. Begitu juga halnya dengan mata pelajaran Pendidikan Agama Islam. Pendidikan Agama Islam merupakan salah satu mata pelajaran yang diberikan dimulai dari SD/MI/SDSLB sampai SMP /MTs/SMPLB. Suryana (2006:36) menjelaskan bahwa Pendidikan Agama Islam dapat dimaknai sebagai usaha sadar dan terencana untuk menyiapkan murid dalam meyakini, memahami, menghayati dan mengamalkan ajaran Islam melalui kegiatan bimbingan, pengajaran dan latihan.

Berdasarkan rumusan tersebut, Kurikulum Pendidikan Agama Islam Sekolah Dasar/Madrasah Ibtidaiyah menjelaskan bahwa Pendidikan Agama merupakan mata pelajaran yang dimaksudkan untuk peningkatan potensi spiritual dan membentuk peserta didik agar menjadi manusia yang beriman dan bertakwa kepada Tuhan Yang Maha Esa dan berakhlak mulia. Akhlak mulia mencakup etika, budi pekerti, dan moral sebagai perwujudan dari pendidikan Agama. Peningkatan potensi spritual mencakup pengenalan, pemahaman, dan penanaman nilainilai keagamaan, serta pengamalan nilai-nilai tersebut dalam kehidupan individual ataupun kolektif kemasyarakatan. Peningkatan potensi spritual tersebut pada akhirnya bertujuan pada optimalisasi berbagai potensi yang dimiliki manusia yang aktualisasinya mencerminkan harkat dan martabatnya sebagai makhluk Tuhan (Depdiknas, 2009:1).

Berdasarkan pendapat yang telah diuraikan sebelumnya, dapat disimpulkan bahwa mata pelajaran Pendidikan Agama Islam pada dasarnya bertujuan untuk peningkatan potensi spiritual dan membentuk peserta didik agar menjadi manusia yang beriman dan bertakwa kepada Tuhan Yang Maha Esa dan berakhlak mulia. Sehingga dapat dipahami mata pelajaran Pendidikan Agama 
Islam merupakan mata pelajaran yang perlu mendapat perhatian, agar siswa dapat menguasainya dengan baik.

Berdasarkan pengamatan sementara yang peneliti laksanakan pada tanggal 05 Februari 2018 di kelas V SDN 9 Pekanbaru, diketahui bahwa dari 22 orang siswa hanya 54,55\% siswa atau 12 orang yang mendapatkan nilai di atas KKM (Kriteria Ketuntasan Minimum) yaitu di atas 70. Dari beberapa gejala-gejala di atas, dapat disimpulkan bahwa hasil belajar Pendidikan Agama Islam pada siswa kelas V SDN 9 Pekanbaru masih tergolong rendah. Salah satu solusi yang dipandang memberikan kontribusi dalam upaya perbaikan pembelajaran Pendidikan Agama Islam adalah strategi index card match. Menurut Suprijono (2010:120) strategi index card match disebut juga strategi mencari pasangan kartu adalah strategi yang cukup menyenangkan digunakan untuk mengulangi materi pembelajaran yang diberikan sebelumnya.

Silbermen (2009:250) menyatakan bahwa kelebihan strategi index card match antara lain dapat membiasakan siswa untuk bekerjasama, saling membantu dan merangsang siswa untuk berfikir secara aktif. Siswa diberikan suatu kebebasan untuk mencari dan menemukan pasangan dari jawaban sehingga siswa cenderung menjadi aktif dan hasil belajarpun cendrung meningkat.

Berdasarkan hal tersebut, peneliti yang juga sebagai guru kelas ingin melakukan penelitian sederhana melalui Penelitian Tindakan Kelas (PTK) dengan judul "Penerapan Strategi Index Card Match untuk Meningkatkan Hasil Belajar Pendidikan Agama Islam pada Siswa Kelas V SDN 9 Pekanbaru". Dengan permasalahan yang telah dirumuskan adalah: "apakah penerapan strategi index card match dapat meningkatkan hasil belajar Pendidikan Agama Islam Pada siswa kelas V SDN 9 Pekanbaru? Berdasarkan rumusan masalah di atas maka yang menjadi tujuan penelitian ini yaitu: untuk mengetahui peningkatan hasil belajar Pendidikan Agama Islam Pada siswa kelas V SDN 9 Pekanbaru dengan penerapan strategi index card match. Pelaksanaan penelitian ini diharapkan dapat bermanfaat bagi berbagai pihak. Antara lain bagi siswa diharapkan dapat meningkatkan hasil belajar Pendidikan Agama Islam pada siswa kelas V SDN 9 Pekanbaru, dan meningkatkan pemahaman siswa pada mata pelajaran Pendidikan Agama Islam.

\section{METODOLOGI}

Penelitian ini dilaksanakan di SDN 9 Pekanbaru, khususnya pada kelas V. Waktu penelitian ini dilaksanakan pada semester II tahun ajaran 2017-2018. Subjek pada penelitian ini adalah semua partisipan yang terlibat dalam penelitian, terutama peneliti, observer, dan siswa kelas V SDN 9 Pekanbaru tahun pelajaran 2017/2018 dengan jumlah siswa adalah 22 orang, terdiri dari 12 orang siswa laki-laki dan 10 orang siswi perempuan. Metode penelitian ini berbentuk Penelitian Tindakan Kelas yang dilaksankan sebanyak 2 siklus, dan tiap siklus terdiri dari 2 kali pertemuan. Arikunto (2010:16) menyatakan bahwa Penelitian Tindakan Kelas (Classroom Research) merupakan suatu bentuk refleksi diri yang dilakukan oleh para partisipan (guru, siswa, atau kepala sekolah) dalam situasi-situasi sosial (termasuk pendidikan) untuk memperbaiki rasionalitas dan kebenaran praktik-praktik sosial atau pendidikan yang dilakukan sendiri. Alur PTK dalam penelitian ini terdiri dari perencanaan, pelaksanaan, observasi, dan refleksi.

Teknik pengumpulan data yang digunakan dalam penelitian ini adalah teknik observasi, teknik tes, dan teknik dokumentasi. Teknik analisis data yang digunakan dalam mengolah data penelitian ini adalah dengan menggunakan teknik penelitian deskriptif dengan penghitungan persentase. Adapun proses pelaksanaannya adalah apabila seluruh data telah terkumpul laku akan dikelompokkan ke dalam jenis data masing-masing yaitu data kualitatif dan data kuantitatif. Data kualitatif akan digambarkan dengan analisis deskriptif atau digambarkan dengan kata-kata. Sedangkan data kuantitatif akan di analisis dengan menggunakan rumus 


\section{Aktivitas Guru dan Siswa}

Setelah data terkumpul melalui observasi, data tersebut diolah dengan menggunakan rumus persentase, yaitu sebagai berikut:

$$
\mathrm{P}=\frac{F}{N} X 100
$$

Keterangan:

$$
\begin{array}{ll}
\mathrm{P} & =\text { Angka Persentase aktivitas guru } \\
\mathrm{F} & =\text { Frekuensi aktivitas guru } \\
\mathrm{N} & =\text { Jumlah indikator } \\
100 \% & =\text { Bilangan tetap (Sudijono, 2004:43) }
\end{array}
$$

Tabel 1 Interval Kategori Aktivitas Guru dan Siswa

\begin{tabular}{lcc}
\hline No & Interval (\%) & Kategori \\
\hline 1 & $76 \%-100 \%$ & Baik \\
2 & $56 \%-75 \%$ & Cukup \\
3 & $40 \%-55 \%$ & Kurang \\
4 & $<40$ & Tidak Baik \\
\hline
\end{tabular}

\section{Hasil Belajar Siswa}

Setelah hasil belajar siswa diperoleh melalui tes, maka langkah selanjutnya melihat ketuntasan belajar siswa secara individu dan klasikal. Untuk menentukan ketuntasan individu rumus yang digunakan yaitu:

$$
K B S I=\frac{\mathrm{T}}{\mathrm{Jt}} x 100
$$

Keterangan :

KBSI = Ketuntasan belajar siswa secara individu

$\mathrm{T}=$ Jumlah skor yang diperoleh siswa

Tt $\quad=$ Jumlah Skor Total. (Trianto, 2008:171)

Sedangkan untuk menentukan ketuntasan secara klasikal rumus yang digunakan yaitu:

$$
K B S I=\frac{\mathrm{JT}}{\mathrm{JS}} \times 100
$$

Keterangan:

$\mathrm{KK}=$ Ketuntasan Klasikal

JT = Jumlah Siswa yang Tuntas

JS = Jumlah Siswa Keseluruhan. (Trianto, 2008:171)

Adapun kriteria penilaian hasil belajar siswa dalam proses pembelajaran Pendidikan Agama Islam dapat dilihat pada tabel beriktu:

Tabel 2 Kategori Hasil Belajar

\begin{tabular}{rrr}
\hline No & Interval (\%) & Kategori \\
\hline 1. & $85-100$ & Sangat Baik \\
2. & $71-84$ & Baik \\
3. & $65-70$ & Cukup \\
4. & Kurang dari 65 & Kurang \\
\hline
\end{tabular}




\section{HASIL DAN PEMBAHASAN}

\section{Deskripsi Hasil Penelitian Siklus I}

Tindakan penelitian pada pertemuan 1 siklus I dilaksanakan pada hari Rabu tanggal 04 April 2018. Indikator yang dicapai adalah: 1) menyebutkan pengertian puasa menurut bahasa dan istilah, 2) menyebutkan dalil tentang puasa Ramahdan, dan 3) menyebutkan cara untuk mengetahui datangnya bulan Ramadhan. Tindakan penelitian pada pertemuan 2 siklus I dilaksanakan pada hari Rabu tanggal 11 April 2018. Indikator yang dicapai adalah: 1) menyebutkan syarat wajib puasa, 2) menyebutkan syarat sah puasa, dan 3) menyebutkan rukun puasa.

\section{Hasil Pengamatan Aktivitas Guru Siklus I}

Hasil pengamatan aktivitas guru dengan penerapan strategi index card match pada siklus I dapat dilihat pada tabel berikut. Secara rinci dapat dilihat pada (Lampiran 7).

Tabel 3 Hasil Pengamatan Aktivitas Guru dengan Penerapan Strategi Index Card Match Pada Siklus I

\begin{tabular}{rrrrr}
\hline No & Siklus & Pertemuan & Aktivitas Guru (\%) & Kategori \\
\hline 1 & I & Pertama & $63,46 \%$ & Cukup Baik \\
& & Kedua & $71,15 \%$ & Cukup Baik \\
& & Rata-rata & $67,31 \%$ & Cukup Baik \\
\hline
\end{tabular}

Berdasarkan tabel di atas, dapat dijelaskan bahwa pertemuan I di siklus I aktivitas guru dikategorikan cukup baik dengan persentase 63,46\%, pada pertemuan 2 meningkat menjadi $71,15 \%$ dengan kategori cukup baik. Secara keseluruhan aktivitas guru dengan penerapan strategi index card match pada siklus I adalah 67,31\% atau dengan kategori cukup baik.

\section{Hasil Observasi Aktivitas Siswa Pada Siklus I}

Aktivitas siswa dengan penerapan strategi index card match pada siklus I dapat dilihat pada tabel 4.3 berikut. Secara rinci dapat dilihat pada (Lampiran 8).

Tabel 4 Hasil Pengamatan Aktivitas Siswa dengan Penerapan Strategi Index Card Match Pada Siklus I

\begin{tabular}{rrrrr}
\hline No & Siklus & Pertemuan & Aktivitas Siswa (\%) & Kategori \\
\hline 1 & I & Pertama & $65,03 \%$ & Cukup Baik \\
& & Kedua & $72,73 \%$ & Cukup Baik \\
& Rata-rata & $69,58 \%$ & Cukup Baik \\
\hline
\end{tabular}

Berdasarkan tabel di atas, diketahui bahwa aktivitas siswa dengan penerapan strategi index card match pada pertemuan 1 siklus I hanya mencapai persentase 65,03\% dengan kategori cukup baik. Pertemuan 2 siklus I hanya mencapai persentase $72,73 \%$ dengan kategori cukup baik. Secara keseluruhan rata-rata aktivitas siswa pada siklus I adalah 69,58\% dengan kategori cukup baik.

\section{Hasil Belajar Tes Siklus I}

Hasil belajar Pendidikan Agama Islam siswa kelas V SDN 9 Pekanbaru setelah penerapan strategi index card match pada siklus I mengalami peningkatan dari sebelumnya. Secara rinci hasil ulangan Pendidikan Agama Islam siswa kelas V SDN 9 Pekanbaru setelah penerapan strategi index card match pada siklus I dapat dilihat pada tabel 4.4 berikut. 
Tabel 5 Hasil Belajar Pendidikan Agama Islam Pada Siswa Kelas VSDN 9 Pekanbaru Pada Siklus I

\begin{tabular}{|c|c|c|c|c|}
\hline \multirow{2}{*}{ No } & \multirow{2}{*}{ Interval (\%) } & \multirow{2}{*}{ Kategori } & \multicolumn{2}{|c|}{ Siklus I } \\
\hline & & & $\mathbf{N}$ & $\%$ \\
\hline 1 & $85-100$ & (Amat baik) & 6 & $27,27 \%$ \\
\hline 2 & $71-84$ & (Baik) & 6 & $27,27 \%$ \\
\hline 3 & $65-70$ & (Cukup) & 4 & $18,18 \%$ \\
\hline 4 & $<65$ & (Kurang) & 6 & $27,27 \%$ \\
\hline \multicolumn{3}{|c|}{ Jumlah } & 22 & $100.00 \%$ \\
\hline
\end{tabular}

Berdasarkan tabel di atas, maka dapat disimpulkan bahwa pada siklus I rata-rata hasil belajar siswa mencapai 74,55 dengan kategori baik. Ini berarti rata-rata hasil belajar siswa mengalami peningkatan dari 65,45 pada sebelum penerapan strategi index card match menjadi 74,55 pada siklus I. Artinya siswa menunjukkan antusiasnya ketika mengikuti proses pembelajaran yang dilaksanakan guru, selain itu siswa mulai dapat menerima pelajaran dengan baik.

Melihat interval nilai siswa, maka diperoleh siswa yang memperoleh nilai sangat baik berjumlah 6 orang (26.27\%), siswa yang memperoleh nilai baik berjumlah 6 orang $(27.27 \%)$, siswa yang mendapatkan nilai cukup tidak berjumlah 4 orang $(18.18 \%)$, dan siswa yang memperoleh nilai kurang berjumlah 6 orang (27.27\%). Jika dilihat dari tingkat ketuntasan siswa, maka pada siklus I jumlah siswa yang tuntas mencapai 16 orang siswa (72.73\%), dan jumlah siswa yang tidak tuntas mencapai 6 orang (27.27\%). Artinya pada siklus I persentase ketuntasan siswa belum mencapai $75 \%$, oleh karena itu perbaikan pembelajaran akan dilanjutkan pada siklus II.

\section{Refleksi Siklus I}

Berdasarkan hasil tes pada siklus I, diketahui bahwa jumlah siswa yang tuntas berjumlah 16 orang siswa atau $72,73 \%$, sedangkan yang tidak tuntas berjumlah 6 orang siswa atau $27.27 \%$. Adapun penyebab siswa yang tidak tuntas adalah: 1) siswa tersebut masih kurang antusias mendengarkan guru menyampaikan materi pembelajaran, sehingga kurang dapat menguasai pelajaran dengan baik, 2) siswa masih kebingungan ketika menemukan pasangan, dan 3) kurang dapat menciptakan suasana kelas yang tenang ketika telah duduk bersama pasangan mereka.

Sedangkan kekurangan dari guru adalah: 1) apersepsi dan motivasi yang guru berikan masih kurang respon dari siswa, karena langsung diberikan guru tanpa pengantar terlebih dahulu, sehingga siswa seperti terkejut ketika guru memberikan pertanyaan, 2) pembagian kartu belum terlaksana dengan tertib, karena seluruh siswa maju mengambil kartu, 3) kemudian guru belum menetapkan waktu kegiatan menemukan pasangan, sehingga masih terlalu lama, dan belum tertib, 4) guru kurang mengarahkan siswa yang telah menemukan pasangannya untuk duduk berpasangan, sehingga ketertiban belum terlihat.

Untuk pertemuan selanjutnya sebaiknya guru harus 1) terlebih dahulu memberikan pengantar yang lebih menarik kepada siswa sebelum memberikan apersepsi dan motivasi, siswa tidak terkejut ketika guru memberikan pertanyaan, 2) membagikan kartu kepada setiap siswa dengan cara memberikan siswa yang duduk di depan terdahulu, kemudian meminta siswa untuk mengopor kepada siswa dibelakangnya, sehingga proses pembagian kartu menjadi lebih cepat, 3) sebaiknya guru menetapkan waktu kegiatan menemukan pasangan, agar tidak terlalu lama pelaksanaan kegiatan ini, 4) sebaiknya guru mengarahkan dan membimbing siswa yang telah menemukan pasangannya untuk duduk berpasangan. Berdasarkan refleksi siklus I, maka penelitian ini dilanjutkan ke siklus II.

\section{Deskripsi Hasil Penelitian Siklus I}

Tindakan penelitian pada pertemuan 1 siklus II dilaksanakan pada hari Rabu tanggal 18 April 2018. Indikator yang dicapai adalah: 1) menyebutkan hal-hal yang membatalkan puasa, 2) menyebutkan sunah puasa, dan 3) menyebutkan niat puasa. Tindakan penelitian pada pertemuan 2 
siklus II dilaksanakan pada hari Rabu tanggal 25 April 2018. Indikator yang dicapai adalah: 1) menyebutkan doa berbuka puasa, dan 2) menyebutkan hikmah puasa Ramadhan.

\section{Hasil Pengamatan Aktivitas Guru Siklus II}

Hasil pengamatan aktivitas guru dengan penerapan strategi index card match pada siklus II dapat dilihat pada tabel berikut. Secara rinci dapat dilihat pada (Lampiran 7).

\section{Tabel 6 Hasil Pengamatan Aktivitas Guru dengan Penerapan} Strategi Index Card Match Pada Siklus II

\begin{tabular}{rrrrr}
\hline No & Siklus & Pertemuan & Aktivitas Guru (\%) & Kategori \\
\hline \multirow{2}{*}{1} & II & Pertama & $82,69 \%$ & Baik \\
& & Kedua & $92,31 \%$ & Baik \\
& & Rata-rata & $87,50 \%$ & Baik \\
\hline
\end{tabular}

Berdasarkan tabel di atas, dapat dijelaskan bahwa pertemuan I di siklus II aktivitas guru dikategorikan baik dengan persentase 82,69\%, pada pertemuan 2 meningkat menjadi $92,31 \%$ dengan kategori baik. Secara keseluruhan aktivitas guru dengan penerapan strategi index card match pada siklus II adalah $87,50 \%$ atau dengan kategori baik.

\section{Hasil Observasi Aktivitas Siswa Pada Siklus II}

Aktivitas siswa dengan penerapan strategi index card match pada siklus II dapat dilihat pada tabel 4.6 berikut. Secara rinci dapat dilihat pada (Lampiran 8).

Tabel 7 Hasil Pengamatan Aktivitas Siswa dengan Penerapan Strategi Index Card Match Pada Siklus II

\begin{tabular}{rrrrr}
\hline No & Siklus & Pertemuan & Aktivitas Siswa (\%) & Kategori \\
\hline \multirow{2}{*}{1} & II & Pertama & $80,77 \%$ & Baik \\
& & Kedua & $84,97 \%$ & Baik \\
& & Rata-rata & $84,27 \%$ & Baik \\
\hline
\end{tabular}

Berdasarkan tabel di atas, diketahui bahwa aktivitas siswa dengan penerapan strategi index card match pada pertemuan 1 siklus II hanya mencapai persentase 80,77\% dengan kategori baik. Pertemuan 2 siklus II hanya mencapai persentase $84,97 \%$ dengan kategori baik. Secara keseluruhan rata-rata aktivitas siswa pada siklus II adalah 84,27\% dengan kategori baik.

\section{Hasil Belajar Tes Siklus II}

Hasil belajar Pendidikan Agama Islam siswa kelas V SDN 9 Pekanbaru setelah penerapan strategi index card match pada siklus II mengalami peningkatan dari siklus I. Secara rinci hasil ulangan Pendidikan Agama Islam siswa kelas V SDN 9 Pekanbaru setelah penerapan strategi index card match pada siklus II dapat dilihat pada tabel 4.7 berikut.

\section{Tabel 8 Hasil Belajar Pendidikan Agama Islam Pada Siswa Kelas V} SDN 9 Pekanbaru Pada Siklus II

\begin{tabular}{rrrr}
\hline No & Interval (\%) & N & Siklus II \\
& & 12 & $54,55 \%$ \\
\hline 1 & $85-100$ (sangat baik) & 6 & $27,27 \%$ \\
2 & $71-84$ (baik) & 2 & $9,09 \%$ \\
3 & $65-70$ (cukup) & 2 & $9,09 \%$ \\
4 & $<65$ (kurang) & 22 & $100.00 \%$ \\
\hline
\end{tabular}


Dari tabel di atas, maka dapat disimpulkan bahwa pada siklus II rata-rata hasil belajar siswa mencapai 85,00 dengan kategori sangat baik. Ini berarti rata-rata hasil belajar siswa mengalami peningkatan dari 74,55 pada siklus I menjadi 85,00 pada siklus II. Artinya pada siklus II siswa dapat mengikuti proses pembelajaran dengan baik, fokus mendengarkan guru menjelaskan materi pelajaran, dan lebih serius dalam menemukan pasangan.

Berdasarkan nilai siswa, maka diperoleh siswa yang memperoleh nilai sangat baik berjumlah 12 orang $(54.55 \%)$, siswa yang memperoleh nilai baik berjumlah 6 orang $(27.27 \%)$, siswa yang mendapatkan nilai cukup tidak berjumlah 2 orang $(9.09 \%)$, dan siswa yang memperoleh nilai kurang berjumlah 2 orang $(9.09 \%)$. Jika dilihat dari tingkat ketuntasan siswa, maka pada siklus II jumlah siswa yang tuntas mencapai 20 orang siswa (90.91\%), dan jumlah siswa yang tidak tuntas hanya berjumlah 2 orang $(9.09 \%)$. Artinya pada siklus II persentase ketuntasan siswa telah mencapai $75 \%$, sehingga dapat disimpulkan bahwa perbaikan pembelajaran pada siklus II dapat dikatakan berhasil.

\section{Refleksi Siklus II}

Berdasarkan hasil penelitian pada siklus II, diketahui bahwa siswa yang tuntas mencapai 20 orang siswa atau dengan persentase 90,91\%. Jumlah siswa yang tuntas meningkat, yaitu dari 16 orang $(72,73 \%)$ menjadi 20 orang $(90,91 \%)$. Dengan demikian keberhasilan siswa pada siklus II telah melebihi $75 \%$, untuk itu penelitian ini hanya dilakukan sebanyak 2 siklus. Keberhasilan ini disebabkan guru dan siswa telah melaksanakan strategi index card match dengan benar dan tepat sesuai dengan langkah-langkah yang telah dijelaskan pada bagian teori, sehingga sangat berdampak terhadap hasil belajar siswa, yaitu hasil belajar siswa meningkat dari sebelum tindakan sampai siklus II.

\section{Pembahasan Hasil Penelitian}

Rekapitulasi aktivitas guru dengan penerapan strategi index card match dari siklus I hingga siklus II dapat dilihat pada tabel berikut.

Tabel 9 Peningkatan Aktivitas Guru dengan Penerapan Strategi Index Card Match Pada Siklus I dan Siklus II

\begin{tabular}{rrrr}
\hline No & Siklus & Persentase (\%) & Kategori \\
\hline 1. & I & $67,31 \%$ & Cukup Baik \\
2. & II & $87,50 \%$ & Baik \\
\hline
\end{tabular}

Berdasarkan tabel di atas, dapat disimpulkan bahwa aktivitas guru dengan penerapan strategi index card match mengalami peningkatan dari siklus I ke siklus II sebesar 20,19\%. Hasil observasi terhadap aktivitas siswa dengan penerapan strategi index card match pada siklus I tergolong "Cukup Baik", dengan persentase 69,58\%. Siklus II meningkat tergolong "Baik" dengan persentase $84,27 \%$. Rekapitulasi aktivitas siswa dengan penerapan strategi index card match dari siklus I hingga siklus II dapat dilihat pada tabel berikut.

Tabel 10 Peningkatan Aktivitas Siswa dengan Penerapan Strategi Index Card Match Pada Siklus I dan Siklus II

\begin{tabular}{rrrr}
\hline No & Siklus & Aktivitas Siswa (\%) & Kategori \\
\hline 1 & I & $69,58 \%$ & Cukup Baik \\
2 & II & $84,27 \%$ & Baik \\
\hline
\end{tabular}

Berdasarkan tabel di atas, dapat disimpulkan bahwa aktivitas siswa dengan penerapan strategi index card match mengalami peningkatan dari siklus I ke siklus II sebesar 14,69\%. Hasil 
belajar siswa dari sebelum penerapan strategi index card match mengalami peningkatan hingga ke siklus II. Untuk lebih jelas dapat dilihat pada tabel berikut.

\section{Tabel 11 Peningkatan Ketuntasan Hasil Belajar Siswa Dari Sebelum Tindakan, Siklus I dan Siklus II}

\begin{tabular}{rrrr}
\hline No & Siklus & Rata-Rata & Ketuntasan (\%) \\
\hline 1. & Data Awal & 65.45 & $12(54,55 \%)$ \\
2. & I & 74,55 & $16(72,73 \%)$ \\
3. & II & 85.00 & $20(90,91 \%)$ \\
\hline
\end{tabular}

Berdasarkan tabel peningkatan hasil belajar Pendidikan Agama Islam siswa kelas V SDN 9 Pekanbaru di atas, dapat disimpulkan bahwa terjadinya peningkatan dari setiap siklus disebabkan guru telah melaksanakan strategi index card match secara benar dengan menguasai langkah-langkah strategi index card match sebaik mungkin.

Berdasarkan tabel rekapitulasi di atas, dapat disimpulkan bahwa besar peningkatan dari sebelum penerapan strategi index card match ke siklus I sebesar 21,74\%. Sedangkan peningkatan hasil belajar siswa dari siklus I ke siklus II sebesar 18,18\%. Sehinga secara keseluruhan hasil belajar Pendidikan Agama Islam siswa kelas V SDN 9 Pekanbaru telah terjadi peningkatan sebesar 36,36\%. Silbermen (2009:250) menjelaskan bahwa "strategi index card match adalah salah satu strategi pembelajaran yang dapat membiasakan siswa untuk bekerjasama, saling membantu dan merangsang siswa untuk berfikir secara aktif, siswa diberikan suatu kebebasan untuk mencari dan menemukan pasangan dari jawaban, dan Siswa cenderung menjadi aktif dan hasil belajarpun cenderung meningkat.

\section{KESIMPULAN DAN SARAN}

\section{Kesimpulan}

Berdasarkan hasil analisis data pada bab IV di atas, dapat disimpulkan bahwa pada sebelum penerapan strategi index card match ketuntasan belajar siswa hanya mencapai 12 (54,55\%), siklus I meningkat menjadi 16 (72,73\%), dan siklus II meningkat lagi menjadi 20 (90,91\%). Besar peningkatan dari sebelum penerapan strategi index card match ke siklus I sebesar 18,18\%. Sedangkan peningkatan hasil belajar siswa dari siklus I ke siklus II sebesar 18,18\%. Sehinga secara keseluruhan hasil belajar Pendidikan Agama Islam siswa kelas V SDN 9 Pekanbaru telah terjadi peningkatan sebesar 36,36\%. Secara keseluruhan dapat disimpulkan bahwa dengan penerapan strategi index card match dapat meningkatkan hasil belajar Pendidikan Agama Islam pada siswa kelas V SDN 9 Pekanbaru

\section{Saran}

Berdasarkan pelaksanaan penelitian dan hasil penelitian yang telah diperoleh, maka peneliti dapat memberikan saran yaitu: penerapan Strategi Index Card Match pada siswa hendaknya disesuaikan dengan tingkat usia dan konten materi, selanjutnya selama proses pembelajaran guru hendaknya cara-cara mengajar yang bervariatif dan menarik perhatian siswa sehingga siswa tidak merasa bosan

\section{REFERENSI}

Ahmadi, Iif, K. (2011). PAIKEM GEMBROT (Mengembangkan Pembelajaran Aktif, Inovatif, Kreatif, Efektif, Menyenangkan, Gembira, dan Berbobot). Jakarta: PT. Prestasi Pustakaraya.

Arikunto, S.. (2010). Penelitian Tindakan Kelas. Jakarta: Rineka Cipta. 
Djamarah, Syaiful, B, dan Zain, A. (2006). Strategi Belajar Mengajar. Jakarta: Rineka Cipta.

Hartono (2010). Analisis Item Instrumen (Analisis Tes Hasil Belajar dan Instrumen Penelitian), Pekanbaru: Zanafa Publishing Bekerjasama dengan Nusa Media Bandung.

Silbermen, M.L. (2009). Active Learning 101 Strategi Pembelajaran Aktif. Yogyakarta: Pustaka Insan Mandiri.

Slameto. (2003). Belajar dan Faktor-Faktor yang Mempengarubinya. Jakarta: Rineka Cipta.

Sudijono, A. (2004). Pengantar Statistik Pendidikan. Jakarta: Raja Grafindo Persada.

Sudjana, N. (2009). Dasar-dasar Proses Belajar Mengajar. Bandung: Sinar Baru Algesindo.

Suprijono, A. (2010). Cooperative Learning: Teori dan Aplikasi PAIKEM, Yogyakarta: Pustaka Pelajar.

Tim Laboratorium Pengembangan Pendidikan \& Pembelajaran Islam (LP3I), (2010). Keterampilan Dasar Mengajar. Yogyakarta: Ar-Ruzz Media.

Trianto. (2008). Mendesain Pembelajaran Kontekstual (Contextual Teaching and Learning) di Kelas. Jakarta: Zaini, dkk. (2007). Strategi Pembelajaran Aktif. Yogyakarta: CTSD. 